\title{
Towards a democratisation of new media spaces in multilingual/multicultural Africa: A heteroglossic account of multilocal and multivoiced counter-hegemonic discourses in Zambian online news media
}

\author{
Felix Banda \\ Department of Linguistics, University of the Western Cape, South Africa \\ E-mail: fbanda@uwc.ac.za
}

\begin{abstract}
This paper explores the production of hybrid cultural identities in Zambian online news websites. Using extracts from five popular online newspapers, namely Lusaka Times, The Post, Kachepa360, Zambia Reports and Zambian Watchdog, the paper shows how writers construct polyphony (many voices) and multiple locality which transcend ethno-linguistic, cultural, geographical/national, orthographic and linguistic boundaries. Through the notion of heteroglossia (Bakhtin 1981), the paper shows how the writers manipulate multiple Zambian languages and English, cultural knowledge and orthographic conventions to achieve various shades of meaning; as well as to produce multiple voices and cultural identities, some of which appear contradictory on the surface but effectively disseminate particular messages. In particular, the paper shows how traditional proverbs and idioms, 'standard' language and spelling systems are used together with so-called "urbanised" and globalised discourses to (re)shape and (re)create language. I argue that what is critical is not knowledge of static and rigid norms of 'traditional' grammar, spelling systems and associated cultures, but an appreciation of how writers manipulate (trans)cultural capital across traditional and modern cultural boundaries and between complementary and contradictory logics. In turn, I argue that to analyse from and to apply 'centre' or 'standard' norms to these discourses is inappropriate and can lead to misinterpretation and misunderstanding of the messages. I conclude that the harnessing and representations of this cultural capital and these diverse voices in the (co)(n)texts not only constitute the peculiarities of the heteroglossic (and even heterotopic) practices of speakers/writers, but also demonstrate that language and 'culture' are products of social activities. Successful deciphering of the cultural materialities of the multilingual (co)(n)texts demands that one divorce the traditional understanding of what constitutes 'language', particularly through decentring 'centre' norms about how language is produced and consumed.
\end{abstract}

Keywords: Zambia, online media, heteroglossia, dialogic, translocal 


\section{Introduction}

The paper is divided into five main sections. The first section describes the sociolinguistic situation in Zambia. The second looks at the relevant theoretical underpinnings and methodological issues. The third and fourth sections explore heteroglossia and multivocality, multilocality and hybridity as discourse practices in Zambian online newspapers. This entails evaluating how newspapers and readers' comments on different news items stylize multiple ethnolinguistic and cultural identities, as well as multiple locality. Of particular interest is how the contradictory logics between standard and non-standard forms of English and Zambian languages, modern (Western) and traditional cultural capital, and conventional ways of writing (including spelling systems) and new media 'abbreviated' writing/textese are used concurrently to create different shades of meaning. Heteroglossia can be said to compel a dialogue between the centripetal and centrifugal socio-ideological forces, with the former being aligned to colonial and hegemonic discourse and the latter to postcoloniality and decentralisation of authority. The resulting hybrid discourses are multivocal, polyphonic and multilingual, and I argue that they represent a rejection of cultural domination and hegemonic existence. The last section summarises how heteroglossic practices serve to decentre so-called "standard" languages, as so-called "periphery" non-standard and unofficial languages take their place in and share the centre of the communicative endeavours. This completes the challenge to the monodiscursive, homophonic and monolingual ideology on which the majority of current 'official' national language practices are premised

\section{The sociolinguistic situation in Zambia}

Zambia is located in south-central Africa. It is said to have more than 72 ethnic groups, who speak 72 related tongues. The languages belong to the Benue-Congo family, a branch of the Niger-Congo family, which in turn is a subdivision of the Niger-Kordofanian family (Kashoki 1978). Specifically, all the languages belong to the Bantu language family. However, not all languages are used in official capacities. For administrative purposes, the Zambian government has demarcated the country into seven linguistic zones. The seven official languages used for local administration are Bemba, Nyanja, Tonga, Lozi, Luvale, Lunda and Kaonde. Although these languages are officially zoned, in practice one hears and reads them outside their official zones. The zoning of languages merely serves to hide the diverse languages in use, which defy strict domain use and other official and social structurings of language. The official elevation of the seven Zambian languages thus does not necessarily stop people from using non-official dialects such as Nsenga, Tumbuka, Soli and Ila (Banda 2015).

The multilingual linguistic dispensation (Aronin and Singleton 2008) is not exactly a new happenstance in Zambia. Marten and Kula (2008:18) argue that "the present-day language situation in Zambia is not so much a product of the colonial era, but is instead based on a dynamic system of multilingualism which has developed over several centuries. A number of the languages which play a part in the contemporary linguistic environment have been spoken - in older forms - in the area since the middle of the last millennium". Banda (2009) notes that people who live in what is now known as "Zambia" are migrants brought together under the colonial banner as a 'nation'. Kaunda's ${ }^{1}$ policy of encouraging inter-ethnic marriages and

\footnotetext{
${ }^{1}$ Kenneth David Kaunda was Zambia's first president after Independence on 24 October 1964.
} 
relocating civil servants to work in regions other than their 'tribal' region has also left its mark, as spouses and children speaking two or more languages is not uncommon.

With the coming of the Europeans, the development of towns and industries only helped to put what was already taking place into sharp perspective. For example, even as the Europeans and missionaries were setting up stations and colonial administrative centres called bomas, the Nguni impis (in Zambia called "Ngoni") were migrating north from the south, triggered by Shaka Zulu's wars of conquest. Some Ngunis settled in Tanzania, while others moved back southwards to settle among the Nsenga, Nyanja/Chewa and Tumbuka-speaking people of Zambia and Malawi. These Nguni warriors did not travel with women; they married local women. Evidently, the war of conquest was not about linguistic domination, as the Nguni adopted and adapted the languages spoken in the societies in which they settled. However, they kept some traditional artifacts such as assegais, cow-hide shields and the foot-stamping war dance called "Ngoma", all of which are displayed during cultural events. The Nguni, or "Ngoni", as they are called in Zambia, speak ciNgoni, a language that shares vocabulary and grammar with Nsenga and has more than $91 \%$ mutual intelligibility with the latter (Kashoki and Mann 1978).

In the late 1960s to early 1970s, multilingualism and multiculturalism were evident in the emerging towns and urban centres whose development was fuelled by copper from what was called the "Copperbelt", which runs from central Zambia to the southern part of the Democratic Republic of Congo. Kashoki (1975) found diverse linguistic features from inter alia Afrikaans, Portuguese and Arabic in what he called "Town" Bemba, as a way to distinguish it from the official dialect of Bemba as spoken in the northern parts of the country (Luapula Province and Northern Province). Kashoki (1975) was one of the first linguists to chronicle the interaction between 'Town' and 'Country', and to study the interface of various languages in the urban spaces of Zambia. In the 1970s and early 1980s, studies on the multilingual situation in Zambia focused on the interaction between English and Zambian languages (cf. Simukoko 1977; Africa 1983; Haynes 1984; Moody 1985; Chishimba 1985; Banda 1996, 2005). Influenced by contrastive and error analysis frameworks and Larry Selinker's (1972) 'interlanguage' theory, some of these studies were concerned about Zambian languages having a detrimental effect on the acquisition of English - the sole official language of education in Zambia - and ultimately on the teaching of English language and other subjects. Chishimba (1985) and Moody (1985) spurned this monolingual/monoglot perspective, in which England was seen as providing the norms to which speakers of English in the former colonies were expected to adhere. They instead looked at what they called 'Zambian English' and postcolonial Zambian languages as resulting from the language contact interface; that is, the interaction between Zambian languages and English. Moody and Chishimba perceived 'deviations' from the monoglot/monolingual 'norms' of English and Zambian languages as aspects of innovation and stylization of multilingual discourses, rather than as 'errors' resulting from 'incomplete' language acquisition. Chisanga (1987) and Banda (1996, 2005) followed suit by arguing that rather than looking at aspects of the extended linguistic repertoire as 'errors' or 'deviant' linguistic forms, there was a need to focus on the communicative potential of the different linguistic resources at the disposal of the speaker.

The aim of the current paper is to explore how the multilingual/multicultural dispensation is a semiotic resource by means of which Zambians express their extended linguistic repertoire and multiple cultural heritages. In turn, the paper explores the production of hybrid cultural 
identities in Zambian online news websites. I use extracts from online newspapers and reader comments on the various stories to show how writers construct polyphony (many voices) and multiple locality which transcend ethno-linguistic, cultural, geographical/national, orthographic and linguistic boundaries. The notions of 'dialogicality', 'multivocality' and 'heteroglossia' (Bakhtin 1981) are used to frame how the writers manipulate linguistic features of multiple languages (Nyanja, Bemba, Tonga, Lozi and Nsenga, to name a few Zambian languages; as well as English), cultural knowledge, orthographic conventions and knowledge of formal and informal varieties of the various languages to achieve various shades of meaning; as well as to produce multiple voices and cultural identities, some of which are contradictory on the surface but effectively disseminate particular messages. In particular, the paper shows how traditional sayings, proverbs and idioms, 'standard' language and spelling systems are used together with so-called 'urbanised' and globalised discourses to (re)shape and (re)create language for new and multiple meanings. The idea therefore is to explore how the linguistic repertoire and cultural capital at Zambians' disposal give voice to their creativity, as well as to the performance of multiple identities that produce multilocalities and multiculturality.

\section{Theoretical and methodological issues}

Bakhtin's notion of 'multivocality' is used in the current study to account for multiple voices and multilocalities embedded in the online data analysed. Higgins (2009:6) defines "multivocality" as "a set of interlinked concepts ... on voice as well as the multiple perspectives, or speaking positions, articulated through language". She relates the term to "the different voices" or polyphony that single utterances can yield due to "their syncretic nature" (2009:7). The creative blending of language makes the resulting form bivalent (Woolard 1999). That is, the new form belongs to two (or more) languages simultaneously, which leads to multi-voiced usage and to the form having multiple meanings all at once. Multivocality is also used to explain how forces of centralisation based on monoglottism or the belief in a singular 'formal' language with attendant centripetal socio-ideological forces "that serve to unify and centralize the verbalideological world" (Bakhtin 1981:270) are counteracted by anti-hegemonic forces of decentralisation in multilingual and multicultural contexts. Centralisation includes pressures that force the structuring and hierarchization of language as a consequence of globalisation and internationalisation. Decentralisation includes forces that promote the localisation of linguistic forms, including linguistic forms drawn from colonial languages.

Ultimately, my interest is in how Zambians draw on diverse linguistic and cultural materialities from their multiple universes for use as semiotic material in their online writing. The idea is not to look at centripetal and centrifugal socio-ideological forces as mutually exclusive, as that would give credence to the idea of a "unitary language in the triple sense of monodiscursivity, homophony and monolingualism" (Busch 20113 ) and hence acquiesce to cultural domination and hegemony. The idea is to look at the dialogicality of the centripetal and centrifugal socioideological forces and examine how this leads to novel meanings and multiple cultural affiliations.

The kind of linguistic framing described above entails an understanding of language that differs from what is apparent in traditional or mainstream characterisation, in which language is described from a monolingual/monoglot ideological perspective. Auer (2007:326) argues that monolingual descriptions fail to account for bilingual discourse. Aronin and Singleton (2008:4) assert that in postmodern modes of thinking "sets of languages rather than single languages 
now perform the essential function of communication, cognition and identity for individuals and the global community". This conceptualisation entails a shift away from a conceptualisation of multilingualism as bounded units of code and community to a more processual and material approach, which presents "language as a social practice, speakers as social actors and boundaries as products of social action" (Heller 2007:1). In multilingual contexts where certain languages or forms of language are perceived and/or designated to be more privileged than others, speakers become social actors who draw on these (languages) as linguistic resources to challenge, neutralise and sustain relations of power and dominant discourse practices (cf. Pavlenko and Blackledge 2004; Heller 2007). In this regard, Oostendorp and Anthonissen (2014:73) note how the notion of heteroglossia "has been used in studies on literacy, bilingual education and teaching English as a second language ... to explain how different styles, registers, languages and language varieties articulate different kinds of experiences", and by extension how heteroglossia can be used to counter the hegemonic monoglot literacy ideology and language education practices in place.

Therefore, in analysing the effects of heteroglossia, dialogism and multivocality in the negotiation of identities, it is necessary to account for how online writing involves challenging and neutralising fixed normative linguistic forms and identity positions and reaffirming them in new ways (Pavlenko and Blackledge 2004; Doran 2004). This entails appropriation, adaptation and transformation of linguistic and other cultural symbols, which are repurposed for new meanings (Doran 2004). This kind of theorising is designed to account for heteroglossia as a discourse practice and to provide an alternative understanding of multilingualism - an understanding that best captures the dynamic manner in which multilingual people move between languages, and the manner in which "... sets of linguistic resources are afforded for language users in different social and cultural circumstances” (Pietikäinen et al. 2008:81) in the multilingual and multicultural contexts in which Zambian online news is produced and consumed.

The news extracts and reader comments used in this paper were collected from websites with Zambian content: Zambian Report, The Post, Lusaka Times, Zambian Watchdog and Kachepa360 (which has since closed). The extracts were collected between February and October 2011 and March and November 2015. The Post is both in print and online; but the extracts used in this paper are from the online version. The Post's online and print stories tend to be the same, but the former captures breaking news stories as they are happening; stories that would only be available in print the next day. The news covered by the newspapers is mainly national, dealing with politics, economics, and Zambian social and cultural issues. Most of the stories collected in 2011 focus on political campaigns, as Zambia was preparing for presidential and parliamentary elections at the time. Those collected in 2015 cover a wide range of topics.

The extracts I use are those that contain multiple languages or features of languages. The idea is to capture how heteroglossia, dialogism and multivocality are deployed in the linguistic performance and negotiation of multiple identities and production of novel meanings. As they are English news sites, one expects that the articles will be in English; and where words, phrases or sentences from Zambian languages are used, one expects an accompanying English translation. However, this is not always the case. Translations are not always provided, and where they are provided they do not always give a true or complete picture of what was said in the Zambian language. This perhaps explains why Zambian-language texts are increasingly quoted verbatim (with or without translations). Editors' use of direct quotes of texts in Zambian 
languages can be said to be their recognition of the multilingual linguistic dispensation in Zambia. In addition, the editors may be aware that translations do not always capture the subtle meanings embedded in the hybrid form resulting from the juxtaposing of two or more linguistic features from apparently different languages/linguistic systems.

Since I speak 10 Zambian languages and I am familiar with the socio-cultural aspects of the languages, I attempt my own translations of the languages during the analysis of the extracts used in the study. In the analysis I do not only focus on the linguistic aspects, but also address the underlying cultural meanings behind the linguistic forms.

\section{Heteroglossia as discourse practice in Zambian online newspapers}

Newspapers, whether online or print, have increasingly been using so-called "colonial languages" such as English and French alongside African languages in texts (content) and in headlines (Banda 2015). In this regard, the newspapers appear to be guided by how best to capture readers' imagination, and how best to arrive at particular meanings using the diverse linguistic resources at hand. Thus, they challenge the 'fixed' linguistic normative forms (Pavlenko and Blackledge 2004; Heller 2007) and deploy headlines and content made up of linguistic features from what are traditionally seen as autonomous linguistic systems. Social and historical moments and memory also come into play in how the different linguistic features are juxtaposed and exploited for their dialogic meanings. Consider the following headline from the English online newspaper Zambian Watchdog dated 19 March 2015:

\section{Extract 1}

"Zambia si nyoko AB Tells Kambwili"

Andrew Banda (AB) says Chishimba Kambwili should shut up and allow citizens to discuss the President's health. And Andrew says Zambians are yet to see the worst of the PF government. "Chishimba Kambwili should just shut up; we all have a stake in this country. If things go wrong, we must criticise. Kambwili cannot stop us from debating the President's health. Zambia si dziko ya anyina olo awisi Kambwili, koma ni ya tonse ['Zambia does not belong to Kambwili's mother or father; it's for all of us']...

Source: Zambian Watchdog (19 March 2015)

$\mathrm{AB}$ is Andrew Banda, who happens to be the son of the former President Rupiah Banda. "Kambwili" is the surname of Chishimba Kambwili, the Minister of Information of the ruling Patriotic Front Party (PF). Andrew Banda belongs to the opposition United Party for National Development (UPND). The writer of this headline assumes that readers will have prior knowledge of all this information. It is also interesting that si nyoko ${ }^{2}$ (literally 'not your mother') is from the Nsenga or Ngoni languages (henceforth "Nsenga"), both of which are not official languages. There is no translation offered in the heading. It would be difficult to capture the irony and sarcasm and the multilayered meanings in the different voices contained in the interface between the Nsenga linguistic forms and English on the one hand, and the dialogicality resulting from formal (use of surname) and informal (use of abbreviation) English on the other.

\footnotetext{
${ }^{2}$ Each Zambian word is presented in italics, while the gloss is in single quotes '...'.
} 
The reason for the irony and sarcasm becomes clear in the accompanying story, the full understanding of which requires historical and socio-cultural knowledge. In Zambian culture, people in a confrontation might insult each other or each other's relatives, as long as it is not the mother. There is an underlying meaning in this extract and others with -nyoko 'your mother' that your mother's 'things' are sacred, but not necessarily -nyina 'someone's mother's' 'things', 3

It is also interesting that the sentence Zambia si dziko ya anyina olo awisi Kambwili, koma ni ya tonse has linguistic features from Nyanja: Zambia si dziko 'Zambia is not his mother's personal property' and koma 'but'; Nsenga ya anyina, 'his mother's' and koma ni ya tonse 'but belongs to all of us' and phonologised English olo 'or'. This attempt at translation is not only awkward but also long. This in part explains why the online newspaper decided to quote verbatim and have Zambians use their cultural knowledge to come to a precise meaning, which is difficult to capture in the English translation. However, you cannot use anyina and anyoko to refer to your own mother; anyina is always to refer to 'somebody's mother', while anyoko is always used in the second person, as in 'your mother'. Whereas anyina is often used as a form of endearment to honour motherhood, as in anyina Joni 'mother of John', -nyoko is sociopsychologically negatively loaded. It is perceived as extremely offensive and is thus taboo. My mother will always be amama or amai wangu, and not *anyoko/anyina wangu; but anyina Joni 'John's mother', not *anyoko Joni, so that anyoko remains 'your mother' (not 'my mother' or 'his/her mother'). There are grammatical implications in how the two forms can be rendered in a sentence in relation to levels of offense and social taboo.

The author of this article is aware of the subtleties in meanings embedded in the near-synonyms anyina 'mother of' and anyoko 'your mother', as well as how to manipulate Nsenga grammar. Evidently, Andrew did not use -nyoko because doing so would be 'ungrammatical' in Nsenga, but opts for -nyina. He could not use -nyoko unless he was addressing Kambwili face to face. Thus, in Nsenga -nyoko as a swear word is used in direct speech contexts or when quoting someone verbatim. In reported speech, -nyoko changes to -nyina. Thus, those reporting on the swear word do not have to repeat the swear word, as the Nsenga grammar obliges them to use anyina. The writer transgresses this norm. The forms -nyina and -nyoko always carry the honorific marker $a$-. The removal of the honorific marker removes the honour and respect reserved for someone's mother. Since Andrew was being interviewed, he could not have used the term a-nyoko, as the term would only apply if he were speaking with Kambwili (or if he were quoting verbatim what he had told Kambwili) about his mother. Andrew used the term $a$ nyina during the interview. However, the writer does not use a-nyina, which would be the 'grammatical' and less derogatory form. The writer is aware of the pejorative nature of the word -nyoko, which is evident in the context of Andrew's discourse. He risks 'ungrammaticality' by using -nyoko in order to translate the virulence of Andrew's original statement, which would be lost if the 'correct' form a-nyina were used. He has put quotation marks (albeit in the wrong place) in the headline "Zambia si nyoko AB Tells Kambwili" to make the sentence appear 'grammatical' as a verbatim rendition. By dropping the honorific prefix $a$ - from $a$-nyoko, the writer introduces more 'ungrammaticality' and further increases the offense given. In Zambia's socio-cultural contexts, -nyoko is more offensive than a-nyoko. The writer therefore subtly exploits the interface between 'grammatical' and 'ungrammatical' Nsenga for communicative

\footnotetext{
${ }^{3}$ The Bantu morpheme boundary is marked by (-). This is particularly important to understand why nyoko is more offensive as an insult to one's mother than anyoko [a-nyoko].
} 
effect and to transgress socio-cultural taboos without appearing to do so, as the swear word is attributed to Andrew.

In a slight variation on the heading above, another online paper, Zambia Reports, used a different language, Bemba, to reframe the idea of the 'untouchable mother' and in so doing to achieve quite a different outcome. First, the socio-grammatical rules about when to use -nyina and -noko in Bemba are similar to those described above for Nsenga. Note that -nyoko is rendered as - noko in Bemba, so that unlike above, the quotation marks are correctly applied as per 'centre' norms in extract 2:

\section{Extract 2}

\section{Flashback: Zambian Watchdog says GBM Is Corrupt; “Te ndalama Shanoko...”}

The selection of the language, Bemba; the choice of the different linguistic features; and the use of words such as ndalama "money' and "corrupt" are intended to capture the sarcasm and also the hypocrisy of the Zambian Watchdog online newspaper, which two years previously had described Godfrey B. Mwamba (GBM) as corrupt, having acquired his wealth (ndalama) through dubious means. This was when GBM was Minister of Defence in the ruling PF party, but after being fired from government and subsequently defecting to the opposition UPND, the paper was now singing his praises. The rest of the news story reads in part:

Today, GBM is as clean as the UPND can suggest a "corrupt free man" fight for the poor. Which poor? With such language as "te ndalama shanoko ch*****", the UPND found it fit to appoint the man as vice president.

Source: Zambia Reports (23 August 2015)

The choice of Bemba Te ndalama shanoko 'It's not your mother's money' is significant, as GBM has a 'humble' education and is thought to be in the habit of speaking his mother tongue, Bemba. Despite his lack of formal education, GBM is said to be one of the richest Zambians. He has been on national television, including MNET's Africa Magic, discussing his various businesses. The writer could have used Nyanja, Nsenga or any other Zambian language in terms of linguistic form. In almost all Zambian languages the word for "money" or "wealth" is ndalama, and the negation morpheme te- in Bemba is actualised as $s i$ - in Nsenga, Ngoni, Nyanja and other languages. The different voices embedded in the different linguistic resources enable the writer to achieve meanings with minimal linguistic effort. As in the description above, shanoko 'your mother's' (literally 'of mother's') is pejorative. The offensiveness of the insult is further heightened by the dropping of the Bemba honorific marker $b a-$. Normally, sha-ba-noko should be used.

To arrive at comprehensive meanings of the multivocal linguistic features used in the article, one also needs to draw on 'common knowledge' of Zambia's socio-political situation. The PF is thought to be Bemba-dominated, while the UPND is thought to be dominated by the Tonga ethnic group. It needs to be noted that these are perceptions, as not all those who speak Bemba are ethno-linguistically Bemba; and the same is true of those that speak Tonga (Kashoki 1975, 1978; Banda 2005). These perceptions appear to have arisen due to the fact that the founding father of the PF party, Michael Sata, is said to be from the Bisa ethnic group, but spoke Bemba most of the time. The founding father of the UPND, Anderson Mazoka, hailed from Southern 
Province, where the Tonga ethnic group is in the majority. Although the PF is led by the current president Edgar Chagwa Lungu, who is of Nsenga ethnic background, the party is still thought to be a 'Bemba Party' in some quarters. Lungu speaks his mother tongue Nsenga fluently, but also uses English and some Nyanja in Lusaka, and Bemba on the Copperbelt and in the Northern and Luapula Provinces. The extended use of Bemba could be because he was born and grew up in Ndola in the Copperbelt Province, where Bemba is the dominant language. Before he was President, he was an MP for Chawama Township in Lusaka, where Nyanja is the dominant language. This description shows that Lungu has linguistic resources that enable him to cross ethno-linguistic and regional boundaries and affiliate with multiple socio-cultural groups.

\section{Heteroglossia and censorship avoidance}

Writers utilise their extensive knowledge of their linguistic repertoire to come up with novel ways of avoiding censorship. Heteroglossia, multivocality and the creative selection of linguistic resources enable writers to avoid censorship of sexually sensitive matters, or to get away with insults. For instance, Zambian readers will know that the abbreviated form $c h * * * * *$ in extract 2 above is a form used in Zambia for the Bemba word chikala 'penis/prick'. This word is particularly common in the comments made by readers of the stories. The example below shows how the writer manipulates the spelling system to euphemise expressions that may be regarded as obscene and to evade detection by electronic foul-language checkers:

\section{Extract 3}

Regina looks like a man. I bet you a million bucks there's a penus and scrot beneath that dress. She and her imbeecile of a husband together with Rupiah Bozo Clown Banda belong to the gallows in Chimbokaila.

Source: Lusaka Times (31 May 2011)

Penus, scrot, and imbeecile are deliberate misspellings of 'penis', 'scrotum' and 'imbecile', respectively. The word penus is written as it is pronounced in Zambia, and thus has been defamiliarised through phonologisation. The choice of the term used in biology lessons, "scrotum", is a deliberate ploy to avoid the culturally offensive "arsehole". The abbreviated form "scrot", an invention that is not found in English dictionaries, is a further attempt to evade censorship and sound less offensive.

Another common technique is to break words into syllables with full stops and/or slashes, as in "stu/.,p.i/d" and "st/up.i.d" in the following example:

\section{Extract 4}

Chiluhainde You are a very gullible i.d.io/t. How many so called non-Lozis did they maim or kill? Can you and your stu/.,p.i/d murderous lying MMD dogs produce one non-Lozi who was maimed or killed. The violence was from RB's murderous mercenaries who were bused in from other provinces. Those st/up.i.d fliers you are talking about are printed and distributed by your Nyasalander-led govt.

Source: Lusaka Times (3 June 2011) 
However, it is also the case that insults and taboo words in Zambian languages are spelled as if they were English words, as in the example below:

\section{Extract 5}

ubushimbe (spinsterhood) na nyelay yamu gwila mama uyu! I am amazed that after doing so well with the tax issues, she has become as disappointing as ka EL! We simply have inexperienced leaders running the show! Its a good thing she has only one year left on her contract! As for EL, he knows his contract is not going beyond exactly one year from today!

Source: Lusaka Times (12 November 2015)

Ubushimbe 'bachelorhood' is a Bemba word with negative cultural connotations. It is used to refer to men who for whatever reason are unmarried. The word has been recontextualised by the writer to refer to a woman who had said that Zambia should adopt the United States dollar and drop the national currency, the kwacha, because the latter, like the Zimbabwean dollar, had become worthless. More importantly, the writer refers to the woman as having nyelay, loosely translated as 'sexual urge'. This is a rephrasing of the Nyanja/Nsenga/Ngoni nyele 'sexual urge'.

Below we see more examples of misspellings and the use of indigenous Zambian languages to evade censorship.

\section{Extract 6}

ulimbwa sana chikala...wabe bolo uncircumcised how dare u say sh.it about Zed..U jst left Zed probably 4 skool and yo parents were sweatin to get yo damn *AS.S* in Shangai $\mathrm{u}$ foolish chap...Come bak $\mathrm{n}$ mek Zeb a beta place..shangai nyo nyo nyo*fyola*

\section{Extract 7}

Busy wasting taxpayers money and the police's time with such a frivolous case. MxxchwM. No wonder they are unable to attend to real crimes.

\section{Extract 8}

SHERRRRRT ON POINT- IS IT ANY OF THEIR BUSINESS AI? KWATI BA SHAVELE AMA VUZI BA BIKA PA DOOR .... CHIKALAS IF YOUR WEEKEND WAS NOT AS GOOD AS JKS

Source: Kachepa360 (27-31 May 2011)

Extract 6 starts with the Bemba ulimbwa sana chikala 'You're a dog, you prick'. In the next sentence, the writer uses a synonym for 'penis': wabe bolo 'You dick [head]'. He ends with the uku-fyola, that is, the 'ideophonic curse': nyo nyo nyo. He has turned and shortened the word ci-nyo 'arsehole' into ideophones for aesthetic effect and to heighten the intensity of the insult. Similarly, MxxchwM in extract 7 is an attempt at $u k u$-fyola. The letters of the 'word' represent a curse/insult produced by clenching the teeth together and sucking in air from the sides of the mouth. The longer and louder the sound, the higher the intensity of the curse/insult. 
The writer in extract 8 uses capitalisation together with choice taboo words from Zambian languages for effect. He deliberately misspells 'shit' SHERRRRRT and, to further evade censorship, he blends Bemba, Nyanja, Nsenga and English: KWATI BA SHAVELE AMA VUZI BA BIKA PA DOOR 'It's like shaving pubic hair and leaving it on front of the door' ( $k$ wati ba 'it's like'; a-ma 'aug-plural marker prefix' = Bemba; shevele = Bemba/Nyanja phonologised from English 'shave'; vuzi 'pubic hair' = Nyanja; $p a$ 'on' = Nyanja/Nsenga/Bemba, etc.). Chikalas 'pricks' is a blend of the Bemba chikala with the English plural marker $-s$.

\section{Exploiting multilocality: Stylising rural, urban, traditional and late-modern identities}

In the extracts, the interplay between 'standard' or rural forms and urban forms of Nyanja, Nsenga, Bemba and English is palpable. The contrastive use of different registers and sociolects is seen within and across the various texts. In addition, writers exploit the morphosyntactic (and also phonetic) aspects of Bantu languages together with English for different meaning potentials. Morphemes, words, phrases, or entire sentences from local languages, English and other languages are used for maximum communicative and aesthetic effect. Because Zambian languages are agglutinating in nature, writers often exploit the fact that words can be sentences and vice versa.

In the past 20 years, there has been a noticeable increase in the use of multilingualism in traditionally English newspapers in Zambia, indicating that the use of multiple languages increases the popularity and sales of these papers. The media are also aware that due to the overwhelming multilingual dispensation among Zambians, the paper can 'keep it real' by quoting verbatim in whatever language cited. They sometimes translate quotes spoken in Zambian languages, but increasingly they place the original text and translated text side by side.

It would appear that translating African languages into English is a risky exercise, as intricate meanings, especially those embedded in sayings and figurative language, are often lost in translation. Newspaper translations often give a general picture of what is contained in the original text. Including the original text together with the translation means that those unfamiliar with the Zambian language in use will get a general picture, while multilingual Zambians will extract specific meanings from the original source, as they are also likely to be aware of the socio-cultural contexts of use. The extracted story below is illustrative of these arguments. The English and Nsenga texts are placed dialogically and side-by-side to enable multilingual readers of the English newspaper The Post to get the full story. The translated texts do not tell the full story. For this reason, I not only retranslate the texts; I also provide the socio-cultural information that is missing from the original translations.

\section{Extract 9}

My ex-husband was lazy in bed - Dora

By Joseph Mwenda in Petauke

MMD spokesperson Dora Siliya on Thursday revealed to Petauke residents that she divorced her husband because he was lazy in bed. 
And Siliya urged men in Petauke Central Constituency to admire her beauty and soft bums and not each other's beards because the laws of Zambia prohibit homosexuality. Addressing about 500 villagers who attended her rally at Minga Stop Basic School, Siliya, who is MMD parliamentary candidate in the area, urged people not to vote for PF leader Michael Sata because he failed to develop the country when he was in government.

Speaking in Nsenga, Siliya likened Sata to her ex-husband whom she said she chased because he was lazy in bed and failed to give her children.

"Neo niwela kuno kuti nikwatileko nivyale, lomba alumebasu everyday pakuyolala usikuonse ni bombasa... Lomba seo tanakazi tukuti yai uyo nimchiza mkwelekazi tichiti nkhoyani kwanu nkhoyani musakileko ayakine, lomba akolwa tujilijili akuti Dora ningakupase vumo neo, ee! Ningakupase vumo neo, anipasile vumo panja pabanthu?" "II got married in order to bear children. Now my husband, all the time when going to sleep he puts on boxer shorts. Now, us women we call such a person a relief provider to the wife. I said go and find another one. Now he is drunk with tujilijili and he is saying "Dora I can impregnate you". Will he impregnate me from outside in full view of people?"”

Siliya said after she divorced her husband, other women who thought they were more beautiful than her went after him thinking she failed in her marriage.

"Nufuna munikonkhe bwino nikaliyo silizhya. Lomba neo nebautushya olabila tetyo panja. Mphela ayakine asimbi akuti yai a Dora akangiwa chikwati ne nitoleko instead yakuti anikonshye kuti weo chewebautushila nichinji? Ati a Dora akangiwa nitole chikwati pakuti beve ndiye abwino ngako. Lomba apa ochita akati tole kuya nao mung'nda ndiye pakuona ulesi wenebapitikishila neo."

"II want you to follow me well. I have not yet finished. After I chased him, some ladies said Dora has failed in her marriage I will take over from her instead of asking me why I chased him. They thought they were more beautiful but now when they take him into the bedroom, that's when they see the laziness that I chased him for", Dora said.'

"Ni same-same na Sata, a Sata olabila kunja lomba akuti neo ningachite ichi, alimonga niwala munakazi asakonshya kuti muyangu chemuutushila nichinji? Khaliwe ya Sata niipa, kubaona tyala pamenso ooneka kuti khalidwe yao niipa, kupa Sata vote nikuononga, nikutaya mumanzi."

"II's the same with Sata, he is saying now when he is outside government that he can do this. It is like that woman who does not ask why her friend chased the husband. Sata is a bad man, you can tell from his face that he is a bad man and giving him a vote is wasting."

Source: The Post (11 September 2011)

One does not expect an African woman in a typical African village to utter "My ex-husband was lazy in bed" in front of villagers. She is in Minga, a remote area even by Zambian standards, to campaign for re-election as Member of Parliament for Petauke, a rural district in Eastern Zambia. Although Dora has lived and worked in the city of Lusaka, she is aware of who she is talking to and of their culture and traditions. The Nsenga people she is addressing are 
matrilineal, so that traditionally the gender hierarchy is not necessarily male-dominated. Nsenga women are also thought by legend to dominate their men materially and sexually (cf. Epstein 1978), which is implicated in Dora's text below. Dora's references to her "beauty and soft bums" are not by chance. Historically, Nsenga women have been stereotyped as extremely beautiful, loud, opinionated and overly resistant to male domination (see Dear Zambia Social Forum 2014). It has been written that even other 'tribes' such as the Bemba compose songs about the beauty and "sexual attractiveness" of Nsenga women (Mitchell 1956:8; Epstein 1978/2009:13). Mitchell (1956) and Epstein's (1978/2009) descriptions relate to what they call "tribal stereotypes" in the 1940s and 1950s in the melting pot of the urbanising Zambian Copperbelt, where migrants from all corners of the country congregated to look for employment in the mines. Such stereotypes persist, as seen from the recent discussion on the Zambia Social Forum on the subject of common 'tribal' stereotypes in Zambia. Here, the Nsenga stereotype was reprised and discussed extensively.

Unlike other Zambian 'tribes', the rite of passage for Nsenga girls is not necessarily a private one performed only in the seclusion of a house with alangizi 'female counsellors'. According to Taylor (2006:117), the Nsenga are among the 'tribes' that "require that the new initiates be presented to the community after the completion of the program in a sort of coming-out ceremony in which the young woman is expected to perform dances which are suggestive of her abilities as a sexual partner, and so on. In contemporary times, these can be quite public and not limited to the ethnic community; many celebrations have been covered in the national news media". Thus, traditionally, Nsenga women are encouraged to be open-minded and to express themselves openly, to talk back to or chide men, and to flaunt their 'assets'.

Following Mitchell, Epstein (1978:13) warns that although stereotyped dances and accompanying songs characterise a joking relationship, for example between the Bemba and Nsenga ethnic groups, and although "such attitudes can be expressed without giving offence, ... stereotypes also operate outside the dance arena, and in so far as they enter into actual behaviour, can have more serious consequences". Dora is disparaging Michael Sata, the PF leader, who had previously said at an election rally that Dora's husband emuleka 'left her', a euphemism for 'divorced her', because she was ugly. She points to the 'beauty' of her mafiga 'soft bums' [from English 'figure'], and implies that only a gay man would not admire her attractiveness. She quickly notes that Zambian laws prohibit homosexuality.

Dora's speech appears to confirm and contest the stereotypes and social discourses surrounding Nsenga women. More importantly, she seems to challenge what people write about African women being dominated by men. She reverses the roles and statuses often attributed to men and women and gains voice and authority by suggesting that it was the ex-husband who failed to do his duties, including satisfying her sexually. In a speech laced with metaphors and figurative language, Dora likens Sata to her ex-husband. She makes it clear that it was she who terminated the marriage as the husband failed to perform his duties to satisfy her sexually and to enable her to bear children. Speaking to villagers who in the main can be said still to believe that the main purpose of marriage is to have children, she uses this cultural knowledge as her point of departure: Neo niwela kuno kuti nikwatileko nivyale... 'I came here to get married so that I could have children...'.

She is careful not to refer to Sata right from the beginning, as one would do in Western-type discourse in order to get to the point as soon as possible. Doing so would also be culturally 
unwise, as Sata is older than she is, and some of the men in the audience may be uncomfortable with a direct attack on a fellow man. Taylor (2006) notes that in Zambian society age is given more status than gender. She follows this by referring to her ex-husband using honorifics $(a-$ and ba-) lomba alume basu everyday pakuyolala usikuonse ni bombasa... 'now our [honorific] husband (ours) [honorific concord agreement] everyday/all the time when we go to sleep, the whole night he's in tight boxers...'. She uses the nominal class 2 prefix $a$ - and the concordial class 2 prefix $b a$ - of the Bantu language noun class system, which in this case acts as an honorific marker, rather than the expected or 'ordinary' mulume wangu (both class 1 prefixes) 'my husband'. It could be argued that this is a sign of respect towards her ex-husband. However, as is clear from the developing story of the 'nonperforming' husband, it is more likely that she is using her sociolinguistic knowledge that these honorifics also function as augmentative prefixes for aesthetic and pejorative effect.

In the next line she chooses to refer to herself in the inclusive 'we', so that it is not the 'I' (or Dora) but the community who decides to chase away the man who could not give her children because of laziness in bed: Lomba seo tanakazi tukuti yai uyo nimchiza mkwelekazi tichiti nkhoyani kwanu nkhoyani musakileko ayakine... 'Now we/ourselves (who are) women we said "No (meaning 'Yes') that one is just a "male bride/wife helper"'. We said "Go back to your home/village and look for someone else".'

Evidently, Dora is aware of the authoritative and elevated status Nsenga women possess in Nsenga culture. She is also aware of proclitivity towards collective decisions in village settings compared to urban areas where individualism is pronounced. Thus, her constant use of 'we' and 'our' can be said to be designed to appeal to the villagers' inclination to collective responsibility, while simultaneously constructing herself as being one of them. Among the matrilineal cultures such as the Chewa and Nsenga, the man traditionally relocates to the wife's village, where he is expected to work for the wife's family and help the wife bear children. The children belong to the wife (and her family), and heritage, including chieftaincy, is passed down from the maternal side of the family. It can be said that the reverse of mchiza mkwelekazi is makoti ('bride') among the patriarchal cultures such as the Xhosa of South Africa. Whereas among the traditional Nsenga a new family is established close to the wife's family, among the Xhosa it is established close to the groom's family. Thus, a mchiza mkwelekazi who fails to work the land for the well-being of the bride, family and community and is 'lazy in bed' and fails to produce children would be 'chased away' (read: forcibly divorced and sent packing).

The Nsenga have been influenced by Western lifestyles and also the Ngoni, who settled nearby after a long trek from Shaka's kingdom in South Africa. Both the Western (modern) and the Ngoni cultures are predominantly patriarchal. Dora is well aware of this, but she is exploiting the multivocality arising from the interface of modern (patriarchal) and traditional (matrilineal) cultures to arrive at a meaning that depicts her ex-husband as a failure and an undesirable person. The ex-husband does not meet the patriarchal and matriarchal tests, as he has failed to satisfy her needs as 'head' of the family or as 'subordinate/helper' to her. The use of the phrase mchiza mkwelekazi is designed to further her claim that she is a legitimate member of the community privy to the local socio-cultural discourses and that the ex-husband has failed to live up to the community's norms and expectations by failing to do his 'manly' duties. She confirms this argument when she later comes up with euphemisms and figurative language: lomba akolwa tujilijili akuti Dora ningakupase vumo neo, ee! Ningakupase vumo neo, anipasile vumo panja pabanthu? 'When he gets drunk with tujilijili [highly addictive local 'gin' with an 
extremely high alcohol content] he says: "I can make you pregnant", and I say: "Ee!/No way! I can make you pregnant my foot! How can he make me pregnant from outside/in front of people?"' The audience are familiar with community and national discourses that characterise tujilijili as a highly addictive alcohol that also reduces a man's physical strength and libido.

Figuratively, Dora is not just having a conversation with the community, she is also having a dialogue with her ex-husband. This helps her to build a case against him and helps to adduce additional 'evidence' to make her story appear unbiased and credible and not as hearsay. The audience are led to judge for themselves who the culprit was. She also constructs an impossible scenario by drawing on the modern imagery of bombasa 'tight boxers' and the traditional African imagery of trying to make a woman pregnant 'from outside/in front of people' (that is, making a woman pregnant without any (sexual) contact).

She seems to have made her point at this juncture, but not exactly; as she continues to syphon sympathy from the audience by first referring to herself in the first person (' $I$ '):

\section{Nufuna munikonkhe bwino. Nikaliyo silizhya. Lomba neo nebautushya. [S]olabila tetyo panja. \\ "'I want you to follow me well. I haven't finished yet. Me, I chased him. He just doesn't say that outside"”.}

Thereafter, she effortlessly changes to referring to herself in the second and third person. Banda (2005) describes how 'cultured women' use this technique to assume power and status in maledominated societies without appearing to be undermining social roles and gendered statuses.
Mphela ayakine asimbi akuti yai a Dora akangiwa chikwati. Ne nitoleko instead yakuti anikonshye kuti weo chewebautushila nichinji?
"'Some young ladies say: "Dora has failed in her marriage, and I'll take over from her", instead of asking me: "You, why did you chase him [why]?"

She also authenticates the conversation by having a dialogue with the hapless women/woman who want(s) to take her place with 'a lazy man'. She tries to draw sympathy from the audience for the unfortunate women/woman by referring to them/her generically as ayakine 'other/some [women]' and in the third person by means of ati 'they say', as illustrated below:

Ati a Dora akangiwa nitole chikwati pakuti beve ndiye abwino ngako. Lomba apa ochita akati tole kuya nao mung'nda ndiye pakuona ulesi wenebapitikishila neo.

" "They say: "Dora has failed in her marriage. I've found a marriage partner because she/they think they're a better marriage partner than I am. After she/they has/have him and take/s him home, she/they see the 'laziness' for which I chased him."'

It is clear that Dora is using the term ulesi 'lazy' in a metaphorical way, which is missed in the newspaper's translation. It is only when the women take him home that they find out that the man has been chased away not only because he fails to consummate his marriage; they also see for themselves that the man's male member is 'lazy'. Drinking illicit tujilijili 'gin' does not help his cause. 
It is only at the end of Dora's speech that she links the story to the opposition leader Michael Sata. She not only links Sata to the 'lazy' man who boasts about his sexual prowess to the entire world while being 'useless' inside the home; she also links him to those women ('people') who enter into relationships without being fully aware of what they are getting into:

Ni same-same na Sata.A Sata olabila kunja lomba akuti neo ningachite ichi. Alimonga niwala munakazi asakonshya kuti muyangu chemuutushila nichinji? Khaliwe ya Sata niipa. Kubaona tyala pamenso ooneka kuti khalidwe yao niipa. Kupa Sata vote nikuononga; nikutaya mumanzi.

" "This is the same as Sata. Outside government, Sata promises things he cannot deliver if in government. He is also like the woman who doesn't ask her 'friend' why she divorced her husband. Sata's (behaviour is that of) a bad man. You can tell from his face that he is a bad man. Don't waste your vote on him. It'll be like throwing your ballot in a river/stream.",

In the analogy, Dora uses metaphorical language and sayings associated with the rural folk to argue that when Sata was a member of her party, the ruling Movement for Multiparty Democracy (MMD), his performance was dismal. Now that he is no longer a member of the MMD after forming his own party, he promises people socio-economic development, which he failed to deliver when he was in the ruling government. Those people enticed to join Sata's party are likened to the women who wished to marry the husband Dora had divorced for failing to perform his husbandly duties.

In male-dominated societies, Dora's speech could be perceived as inappropriate, as women are not expected to speak about sexual matters, certainly not in an open forum (unless it is to do with clinical matters, including dissemination of information on sexual abstinence, HIV/AIDS and so on) (cf. Banda 2005). However, Dora has used her knowledge of Nsenga culture and language, her city and modern upbringing and prevailing national discourses on the acceptability of homosexuality to fine-tune her campaign message. At the time of this campaign, there was a debate on the 'acceptability' of homosexuality in Zambia, which was triggered by two men who decided to marry in defiance of Zambian law. It is in this context that Dora's apparently innocuous comment that men should "admire her beauty and soft bums and not each other's beards because the laws of Zambia prohibit homosexuality" should be seen. Although Dora is Western-educated and spends most of her time in the capital city of Lusaka, she simultaneously manages to construct herself as a 'traditionalist' and protector of African 'culture and tradition', which is likely to be appreciated in the rural areas. She balances traditional and modern values to acquire a voice which she uses to directly challenge the prevailing sentiments about the duality of male-female social roles and statuses, in which males are seen as dominant (cf. Banda 2005). Furthermore, she gains considerable moral ground by interrogating the socio-cultural power of men in African society. She exploits modern and traditional cultural capital to extend her fight for 'cultural morality' against men such as her exhusband and the opposition's Michael Sata who dare question the sanctity and power of a 'traditional' Nsenga woman. Therefore, Dora uses the dialogicality between modern and traditional cultures and sociolinguistic knowledge of Nsenga euphemisms and figurative language to accomplish agency and voice, which in turn enables her to transform the social role of the 'timid African woman' to an aggressive but 'cultured' woman who questions a man's integrity and 'traditional' authority in an open forum. 


\section{Material culture of multilingualism}

The data analyzed above suggest that the Internet has become the site where the material culture of multilingualism in Zambia is linguistically reflected. Aronin and Ó Laoire (2012:3) perceive material culture as "the study of artefacts and objects as well as landscapes, cityscapes, roadscapes, villages, localities, dwellings, private households and collective homes, public spaces and ways of their organisation and use". Since people label artifacts, events, rituals, experiences and so on with different linguistic forms in multilingual contexts, I want to argue that the study of the material culture of multilingualism is also about the study of shared cultural capital, including linguistic resources, across ethnolinguistic and multilingual cultural groups, as illustrated in this paper. I have shown that Zambians use the multilingual linguistic dispensation to discuss recent and distant events and social issues, as well as immediate and distant physical objects and materialities.

Since the linguistic resources are shared, in the recent past, headlines using Zambian languages were usually not translated into English; not for economy of linguistic resources, but in order to provide maximum aesthetic and informative value, as in the following:

\section{Extract 10}

'UPND Supporters are a proper definition of Ubukopo'

Source: Zambia Reports (12 November 2015)

Cikopo is a Zambian word (as far as I know, all Zambian languages use this word) literally meaning 'tin'. However, it has different shades of meaning in Zambian discourses, as in school/education a cikopo refers to a 'dull learner'. In this sense, cikopo refers to 'empty tin'. In the political discourse of party rivalry, as suggested in the headline, ubu-kopo [state of being a cikopo] is a reference to supporters of the UPND party, who have much to say but fail to say anything of substance; just like a tin makes a noise when it is empty. The inclusion of the augprefix $u b u$ - turns the word into Bemba and related languages. In Nyanja, Tumbuka, Nsenga and other languages, it would be $u$-kopo.

\section{Extract 11}

\section{TODAY'S EDITORIAL COMMENT: Kutumpa}

Source: The Post (4 November 2015)

Kutumpa 'stupid' is a Bemba word which has become integral to the extended Zambian linguistic repertoire. The question is, why use the Bemba word and not the English word? Kutumpa and "stupid" have become specialised terminology: the former is in common use, while the latter is perceived as a serious insult. Historically, during colonial times, white bosses were fond of unfairly admonishing their black employees with the word "stupid". Even the most educated Zambians who are familiar with the English-dictionary meaning of the word avoid it and opt to use the Bemba version, which does not carry social sanction. Both the paper and the President who is being cited use kutumpa, not the English version "stupid". Despite the power he has as president, the audience and Zambians generally would not have taken it well had he used the word "stupid" at a rally; even if this were to castigate teachers for campaigning for the opposition. In part, the main story reads: 
"...But before I go back to Lusaka, I want the civil service to change, maka ba teacher baku Chingola ['especially teachers in Chongola']. Let me take this advantage [sic] to warn those teachers: I will sort you out, you are supposed to serve the people of Zambia, but you are using government resources to campaign for the opposition. Nganamitamfya kutumpa kwenu ['If I fire you, blame your stupidity']'.

The paper does not translate the parts that are in Bemba, as they are aware that most Zambians, regardless of linguistic background, will know what is being said.

Similarly, alangizi 'female counsellors' is a Nyanja word that has now become part of Zambian (and Zambian English) multilingual discourse around growing up, regardless of one's ethnic/linguistic group.

\section{Extract 12}

Mumbi needs alangizi - Ngoma

By Fridah Nkonde

THERE is need for alangizi to sit PF deputy secretary general Mumbi Phiri down and teach her how to respect her husband and men in general, says Levy Ngoma.

And Ngoma, the Sinda MMD member of parliament, says easterners are not tribal people and will not vote for President Edgar Lungu just because he comes from their region.

Commenting on Mumbi's statement that she regrets having children from Eastern Province because people in the region have rejected President Edgar Lungu, who is their own son, Ngoma wondered why Mumbi was fond of undressing and insulting men.

Source: The Post (22 October 2015)

Ku-lang- $a$ means 'to show/teach'. Traditionally, alangizi would counsel other women regarding marriage, nutrition and other socio-cultural issues affecting the family and community wellbeing. Girls and women thought to be 'disrespectful' to elders in particular are advised or recommended to have alangizi teach them manners. Mumbi Phiri, a woman, is said to have disrespected men and her husband by her comments. Mumbi Phiri's words are interpreted as an attack on her husband and men generally, as she is suggesting that she regrets marrying him on account of political differences. In addition, she is "fond of undressing and insulting men", meaning that she exploits men for children and then leaves the men after she has got what she wanted.

\section{Summary and concluding remarks}

Considering the analysis above, it can be argued that there is a deliberate effort to spurn "monodiscursivity, homophony and monolingualism" (Busch 2011:3). The apparent resistance to monocultural domination and hegemonic existence is seen in the interlocutors' exploitation of the interface and dialogicality of the centripetal and centrifugal socio-ideological forces, both of which are used to achieve novel meanings and social relations. In this framing, "heteroglossia 
becomes a counter-strategy that functions as a 'parodic antibody' which challenges and profanes the authoritarian word and brings it back into dialogue" (Bakhtin 1986:133 cited in Busch 2011:3). In this regard all languages have an equal chance to be heard, as there are no minority or majority languages. Following from this, we find that there is a decentring of formal or 'standard' language as the preferred code for meaning-making. Punctuation and other 'formal' grammatical features are optional rather than obligatory. The constant reframing, blurring and levelling of boundaries between English and indigenous languages and among indigenous languages ensures the blurring of language hierarchies and cultural boundaries. Formal and informal linguistic dispensations, as well as modern and traditional and 'town' and 'rural' cultural capital, are brought into dialogue to maximise meaning potentials.

Heteroglossia enables Zambians to affiliate themselves with multiple ethnolinguistic groups, regions and even nationalities. The creativity that goes into the interfacing of the linguistic choices relating to the local/global, traditional/modern, town/country, formal/informal and multiple linguistic resources is empowering to those involved. This leads to a celebration of the integration of diversity and collaboration as well as shared cultural and linguistic knowledge and references, and to further integration of the local/global, traditional/modern lifestyles, the formal/informal linguistic interfaces, and the associated cultural materialities and affiliations.

No doubt developments in media technology, which make it easy to manipulate linguistic features, are also critical in unlocking the creative ability of multilingual/multicultural Zambians to 'speak' across regional, national, linguistic and even ethnic boundaries. This in turn gives them 'voice', as well as a platform to perform multiple identities and to produce multilocalities and hence to affiliate across ethnic, regional and national boundaries. Since different language forms are associated with different social groups, localities and regions/centres, multivocality enables Zambians to belong to several localities, social groups and regions at the same time.

I have shown how traditional sayings and idioms, 'standard' language and spelling systems are used together with so-called 'urbanised' and globalised discourses to (re)shape and (re)create language. Formal or 'standard' forms of written language, whether English or Zambian languages, are used side by side, as if to mirror or neutralise each other. In this sense, the spaces of interaction are democratic. It is clear from the manner in which readers blend features of socalled 'centre' and 'periphery' norms that in most cases they are aware of the static and rigid norms of 'traditional' grammar, spelling systems and associated cultures, while also appreciative of how writers can manipulate (trans)cultural capital across the traditional and modern cultural boundaries and between complementary and contradictory logics. This is what makes the kinds of data analysed in the paper interesting: contradictory logics are entered into dialogue in order to create specific shades of meaning. To apply 'centre' or 'standard' norms to these discourses is inappropriate and can lead to misinterpretation and misunderstanding of the messages and/or the ever-shifting alternative norms in play. The harnessing and representations of this cultural capital and these diverse voices in the (co)(n)texts not only constitute the peculiarities of the heteroglossic (and even heterotopic) practices of speakers/writers, but also demonstrates that language is a product of social activity. In this regard, successful deciphering of the (co)(n)texts demands that one divorces traditional understanding of what constitutes 'language' and particularly 'centre' norms about how language should be written. Heteroglossia or 'mixing' is "socially embedded in African 
historical and contemporary social experiences and uses of language" (Makoni and Mashiri 2006:82).

There is a sense in which the bits and pieces that constitute 'language' emerge from the kinds of interaction and information required in contexts. Seen in this way, it can be said that 'language' emerges from the different practices and contexts. This is in line with Pennycook (2010) and Makoni and Pennycook's (2006) argument about the need to disinvent and reconstitute languages; not as autonomous systems or codes, but as products of social practice. Multivocality is a natural consequence of a multilingual linguistic dispensation, rather than a special instance of language practices in multilingual contexts.

Since multivocality is localised in language practice, the forces of centralisation are neutralised in discourse. There was no complaint from the readers and commentators on the use of multiple languages in what are English-language papers. The use of linguistic features from languages other than English or 'official' Zambian languages was not only 'democratic': it also ensured that different shades of cultural meanings were not lost in translation. It is also interesting that in the data collected since 2011, there have been little or no complaints about spelling or grammar. There seems to be acceptance of decentralisation and localisation. The forces of vertical structuring and hierarchization of languages and cultures are then seen for what they are: social constructs (see Appadurai 1996). Embracing heteroglossia as a discourse practice in multi-ethnic and multilingual societies enables a dialogue between forces of decentralisation and centralisation, which in turn checks the negative effects of inequality and hegemony between languages, ethnic groups and cultures. The different ways of 'doing' language are increasingly being integrated into an extended linguistic repertoire with a transnational character, rather being specific to an ethnolinguistic group. Thus, 'doing' language is increasingly becoming part of Zambia's culture of growing up.

Therefore, in theorising language in the face of the Bakhtinian notions of heteroglossia and Pennycook (2010), Makoni and Pennycook's (2006) and Heller's (2007) idea of language as social practice, we need to be aware that language is not an autonomous system out there (waiting to be appropriated and used); language emerges in localised practices. Similarly, in celebrating language use, new media affordances, globalisation and internationalisation, we need to be cognisant that these are not a function of "what's out there"; rather, they are dictated by the localised practices in multiple localities. Thus, there is a need for a sociolinguistics of globalisation that accounts for the localisation of linguistic and cultural forms. The blending of local, regional, national and international linguistic features and cultural materialities allows innovations in the production of diverse localised meanings and social experiences. These innovations have global implications. In this regard, if forces of centralisation and decentralisation are seen as being in dialogue rather than as mutually exclusive, there is a greater chance of difference and diversity being celebrated and monoculturalism, monodiscursivity, monoglottism and hegemonic existence being disavowed.

\section{References}

Africa, H. 1983. Zambian English: Myth or reality? Unpublished seminar paper. Lusaka: University of Zambia, Department of Literature \& Languages. 
Appadurai, A. 1996. Modernity at large: Cultural dimensions of globalization. Minneapolis: University of Minnesota Press.

Aronin, S. and D. Singleton. 2008. Multilingualism as a new linguistic dispensation. International Journal of Multilingualism 5(1): 1-16.

Aronin, L. and M. Ó Laoire. 2012. The material culture of multilingualism: Moving beyond the linguistic landscape. International Journal of Multilingualism 10(3): 225-235.

Auer, P. 2007. The monolingual bias in bilingualism research, or: Why bilingual talk is (still) a challenge for linguistics. In M. Heller (ed.) Bilingualism: A social approach. New York: Palgrave MacMillan.

Bakhtin, M. 1981. The dialogic imagination: Four essays. M Holquist (ed.), C. Emerson and M. Holquist (trans.) Austin and London: University of Texas Press.

Bakhtin, M. 1986. Speech genres and other late essays. C. Emerson and M. Holquist (ed.) Austin: University of Texas Press.

Banda, F. 1996. The scope and categorization of African English: Sociolinguistic considerations. English World-Wide 17: 163-175.

Banda, F. 2005. Analysing social identity in casual Zambian/English conversation: A systemic functional linguistic approach. Southern African Linguistics and Applied Language Studies 23(3): 217-231.

Banda, F. 2009. Critical perspectives on language planning and policy in Africa: Accounting for the notion of multilingualism. Stellenbosch Papers in Linguistics PLUS 38: 1-11.

Banda, F. 2015. Language policy and orthographic harmonization across linguistic, ethnic and national boundaries in Southern Africa. Language Policy 1-19.

Busch, B. 2011. Building on heteroglossia and heterogeneity: The experience of a multilingual classroom. Presentation held at the 3rd International Conference on Language, Education and Diversity (LED), 22-25 November 2011, Colloquium: Language, Education, and Superdiversity. Auckland: University of Auckland.

Chisanga, T. 1987. An investigation into the form and function of educated English in Zambia as a possible indigenized non-native variety. Doctoral dissertation. York: University of York.

Chishimba, M. M. 1985. Deviation and innovation in English: Zambian examples. Unpublished Seminar Paper. Lusaka: University of Zambia, Department of Literature \& Languages.

Dear Zambia Social Forum. 2014. Available online:

https://www.zambia.co.zm/social/viewtopic.php? $\mathrm{f}=7 \& \mathrm{t}=830 \& \mathrm{p}=23136 \&$ hilit=Nsenga\&sid=0 7ac973521d9ef1221775d56e460303f\#p23136. (Accessed 10 January 2016). 
Doran, M. 2004. Negotiating between Bourge and Racaille: 'Verlan' as youth identity practice in suburban Paris. In A. Pavlenko and A. Blackledge (eds.) Negotiation of identities in multilingual contexts. Clevedon: Multilingual Matters. pp. 93-124.

Epstein, A. L. 1978. Ethos and identity: Three studies in ethnicity. London: Tavistock Publications.

Haynes, R. 1984. A pilot study into the emergence of a non-standard dialect of English in Zambia. Unpublished seminar paper: Department of Education. Lusaka: University of Zambia.

Heller, M.(ed.) 2007. Bilingualism: A social approach. London: Palgrave Macmillan.

Higgins, C. 2009. English as a local language: Postcolonial identities and multilingual practices. Toronto: Multilingual Matters.

Kachepa360. Available online: http://urlm.co/www.kachepa360.com. (Accessed 31 May 2011).

Kashoki, M.E. 1975. Migration and language change: The interaction of town and country. African Social Research 13: 707-729.

Kashoki, M. E. 1978. The language situation in Zambia. In S. Ohanessian and M.E. Kashoki (eds.) Language in Zambia. London: International African Institute. pp. 9-36.

Kashoki, M.E. and M. Mann. 1978. A general sketch of Bantu languages in Zambia. In S. Ohanessian and M.E. Kashoki (eds.) Language in Zambia. London: International African Institute. pp. 47-100.

Lusaka Times. Available online: https://www.lusakatimes.com. (Accessed 10 January 2016).

Makoni, S. and P. Mashiri. 2006. Critical historiography: Does language planning in Africa need a construct of language as part of its theoretical apparatus? In S. Makoni and A. Pennycook (eds.) Disinventing and reconstituting languages. Clevedon: Multilingual Matters Ltd. pp. 93124.

Makoni, S. and A. Pennycook. 2006. Disinventing and reconstituting languages. In S. Makoni and A. Pennycook (eds.) Disinventing and reconstituting languages. Clevedon: Multilingual Matters Ltd. pp. 1-41.

Marten, L. and N.C. Kula. 2008. One Zambia, one nation, many languages. In A. Simpson (ed.) Language and national identity in Africa. Oxford: OUP. pp. 291-313.

Mitchell, J. C. 1956. The Kalela dance: Aspects of social relationships among urban Africans in Northern Rhodesia. Manchester: Manchester University Press.

Moody J. 1985. Zambians talking twenty-five English conversations. Lusaka: Institute for African Studies. 
Pavlenko, A. and A. Blackledge (eds.) 2004. Negotiation of identities in multilingual context. Clevedon: Multilingual Matters.

Oostendorp, M. and C. Anthonissen. 2014. Multiple voices in bilingual higher education: Language choices of Afrikaans/English bilinguals at Stellenbosch University. Per Linguam 30(2): 69-87.

Pennycook, A. 2010. Language as a local practice. New York: Routledge.

Pietikäinen, S., R. Alanen, H. Dufva, P. Kalaja, S. Leppanen and A. Pitkänen-Huhta. 2008. Languaging in Ultima Thule: Multilingualism in the life of a Sami boy. International Journal of Multilingualism 5(2): 79-99.

Selinker, L. 1972. Interlanguage. IRAL 10(3): 209-231.

Simukoko, Y.T. 1977. A preliminary investigation into some factors of Zambian variety of English. M.Phil dissertation. York: University of York.

Taylor, S. C. 2006. Culture and customs of Zambia. London: Glenwood Press

The Post. Available online: http://www.postzambia.com. (Accessed 10 January 2016).

Woolard, K. 1999. Simultaneity and bivalency as strategies in bilingualism. Journal of Linguistic Anthropology 8(1): 3-29.

Zambia Report. Available online: http://www.zambiareports.com. (Accessed 10 January 2016).

Zambian Watchdog. Available online: http://www.zambiawatchdog.com. (Accessed 10 January 2016). 